\title{
Medievalista
}

Online

23 | 2018

Número 23

\section{As crónicas de Zurara: a corte, a aristocracia e a ideologia cavaleiresca em Portugal no século XV}

The chronicles of Zurara: royal court, aristocracy and chivalry in fifteenthcentury Portugal

\section{Miguel Aguiar}

\section{(2) OpenEdition}

\section{Journals}

\section{Edição electrónica}

URL: http://journals.openedition.org/medievalista/1580

DOI: 10.4000/medievalista.1580

ISSN: 1646-740X

\section{Editora}

Instituto de Estudos Medievais - FCSH-UNL

Edição impressa

Data de publição: 1 janeiro 2018

\section{Refêrencia eletrónica}

Miguel Aguiar, «As crónicas de Zurara: a corte, a aristocracia e a ideologia cavaleiresca em Portugal no século XV », Medievalista [Online], 23 | 2018, posto online no dia 07 maio 2018, consultado o 10 dezembro 2020. URL : http://journals.openedition.org/medievalista/1580 ; DOI : https://doi.org/ 10.4000/medievalista. 1580

Este documento foi criado de forma automática no dia 10 dezembro 2020

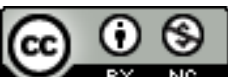

Mediavalista está licenciado com uma Licença Creative Commons - Atribuição-NãoComercial 4.0 Internacional. 


\title{
As crónicas de Zurara: a corte, a aristocracia e a ideologia cavaleiresca em Portugal no século XV
}

\author{
The chronicles of Zurara: royal court, aristocracy and chivalry in fifteenth- \\ century Portugal
}

Miguel Aguiar

\section{NOTA DO EDITOR}

Data recepção do artigo / Received for publication: 25-01-2017

Data aceitação do artigo / Accepted in revised form: 20-10-2017

As crónicas de Zurara: a corte, a aristocracia e a ideologia cavaleiresca em Portugal no século XV /

The chronicles of Zurara: royal court, aristocracy and chivalry in fifteenth-century Portugal Miguel Aguiar

No capítulo 46 da Crónica do Conde D. Duarte de Meneses, depois de cerca de trinta páginas onde se descrevem os episódios que tiveram lugar durante o cerco muçulmano a Alcácer Ceguer, Gomes Eanes Zurara apresenta uma lista com "os nomes daqueles que se a este cerco uyerom pera seruyr deos e seu Rey" ${ }^{1}$. 0 cronista realça trinta e três homens que se terão destacado, aí se encontrando, naturalmente, o "illustre e muy famoso caualleyro dom Duarte de meneses", mas também outros indivíduos pertencentes a linhagens da média e alta nobreza de corte (Vasconcelos, Melo, Távora, Ataíde, Sousa, Noronha, entre outros) $)^{2}$. Depois de arrolados estes nomes, Zurara sublinha que na defesa da praça também participaram outros "nobres homeens e gente", dispensando-se do trabalho de explicitar a sua identidade "por nom causar fastyo". 
2 A lista é o corolário de um ciclo da narrativa em que se descrevem os principais acontecimentos que marcaram o assédio que a segunda praça portuguesa no Magrebe sofreu, decorria o ano de 1459. Aí são percetíveis as dificuldades em aguentar a pressão muçulmana, mas também em gerir as tensões inerentes à própria composição da guarnição. Por isso, e como não podia deixar de ser, o capitão D. Duarte de Meneses é amplamente elogiado. Personificando a autoridade na cadeia de comando e a encarnação da indispensável virtude da prudência, D. Duarte vai fazendo a sensível gestão dos egos e ímpetos bélicos dos fidalgos sob o seu comando, sem deixar, contudo, de dar provas da sua fortaleza - outra virtude essencial - ao desafiar o comandante inimigo para o combate. Ao longo destas páginas são também relatadas as façanhas individuais dos fidalgos portugueses: nas muralhas, nos combates travados na barreira erguida diante da praça - 0 lugar onde "mais onradamente" se podia combater - e também nas rápidas surtidas a cavalo fora das muralhas, organizadas sobretudo para destabilizar as forças inimigas ou para atingir determinados objetivos estratégicos ${ }^{3}$.

3 Os relatos de enfrentamentos militares - cercos, expedições navais, cavalgadas sobre aldeias inimigas - preenchem quase totalmente as diversas obras de Zurara ${ }^{4}$, a ponto de se ter dito que as suas obras convertiam a crónica geral do reino "na crónica dos

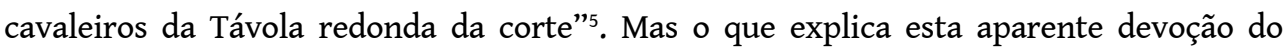
autor pelos modelos narrativos de pendor cavaleiresco? Haverá razões que expliquem os repetitivos e estereotipados capítulos que descrevem façanhas mais ou menos reais de forma grandiloquente? De que forma se podem entender e enquadrar estas obras? o objetivo essencial deste artigo é analisar a produção cronística de Zurara de acordo com o contexto em que foi elaborada, com os objetivos que terão presidido à sua feitura e com os materiais de que o cronista dispôs. Por isso, começarei por me referir sumariamente às diversas obras por si assinadas, aos seus objetivos práticos, à sua relação com a chamada 'crónica geral do reino' e também às fontes que Zurara terá utilizado, procurando demonstrar que todos estes aspetos são fundamentais para compreender o conteúdo e o estilo das obras em questão. Depois, o objetivo é analisar as obras de Zurara enquanto discurso sobre a cavalaria em Portugal no século XV. Ao realçar as perspetivas do cronista e sua relação com aquele que seria o sistema de valores que caracterizava a ideologia cavaleiresca nesta época, procurarei contrapor o discurso de Zurara com outros testemunhos coevos. Uma ideologia que, como se tentará demonstrar, tinha também implicações práticas, cuja tradução, no caso das crónicas assinadas por Zurara, se reflete nomeadamente no seu caráter didático e de exempla, fazendo delas uma espécie de espelhos de nobres ${ }^{6}$ - mais à frente desenvolverei este conceito. Por fim, o derradeiro ponto a considerar nesta linha de inquérito é o papel desempenhado por este conjunto de escritos enquanto elementos de 'propaganda' ao serviço de um dos desígnios constantes no reinado de D. Afonso V: a expansão ultramarina e a cruzada.

\section{A atividade do cronista-mor: entre a crónica-geral do reino e as narrativas que chegaram aos nossos dias}

A atividade de Gomes Eanes de Zurara enquanto cronista-mor do reino estendeu-se entre o final da década de 1440 e o início da década de $1470^{7}$. Entre 1449 e 1450, e com possíveis alterações até 1460 , compôs a Crónica da Tomada de Ceuta ${ }^{8}$. Apesar de ser uma obra 
estruturada como se de uma gesta cavaleiresca se tratasse, foi entendida pela crítica como pertencente à crónica geral do reino, sendo neste caso a peça final da narrativa dedicada ao reinado de D. João I ${ }^{9}$. A Crónica dos Feitos da Guiné, provavelmente composta entre $1452 \mathrm{e}$ 1453 (ou seja, ainda em vida do Infante D. Henrique), e com alterações até 1464, é aquela que suscitou mais problemas eruditos e acesas polémicas entre os especialistas ${ }^{10}$ (discutindo-se, entre outras coisas, a hipótese de resultar de uma fusão entre um livro dedicado aos feitos do Infante e uma narrativa centrada nas navegações e conquistas propriamente ditas ${ }^{11}$ ). O texto relata as navegações e as 'conquistas' portuguesas promovidas pelo Infante D. Henrique ao longo da costa ocidental africana, apresentando inúmeras descrições de expedições militares ${ }^{12}$, em cujos interlúdios se podem encontrar descrições geográficas ou notícias de acontecimentos marcantes como, por exemplo, o célebre episódio da primeira grande venda de escravos negros em Lagos ${ }^{13}$. As duas outras crónicas compõem, juntamente com a narrativa dedicada à conquista de Ceuta, uma espécie de trilogia do Norte de África ${ }^{14}$. Em primeiro lugar, a crónica do Conde D. Pedro de Meneses, composta entre 1458 e 1464, e, finalmente, a Crónica do Conde D. Duarte de Meneses, começada em 1464, depois da morte do capitão de Alcácer Ceguer, e completada até 1469. Ambas apresentam um caráter "híbrido"15, aliando a biografia dos dois exemplares fidalgos ${ }^{16}$ e capitães ao relato pormenorizado dos cercos, recontros e cavalgadas dos portugueses em torno de Ceuta e de Alcácer Ceguer (voltarei à questão do conteúdo destas crónicas mais à frente).

5 Ao longo dos cerca de trinta anos em que ocupou o cargo de cronista-mor, Zurara surge como autor de quatro textos distintos, orientados segundo o propósito de contar uma nova etapa na história do reino, isto é, o que a historiografia convencionou chamar o processo de expansão, mas que os homens de Quatrocentos conceberam como as guerras de Marrocos ou a descoberta de novas terras. Ao mesmo tempo, existia uma espécie de projeto contínuo no que toca à redação da crónica geral do reino ${ }^{17}$, como fica patente em várias partes das obras aqui em análise: "como na cronyca do Regno he contheudo"18, "como na coronica gerall do rregno mais largamente podeys achar" 19 ou "como mays compridamente acharees na cronica do Regnado deste Rey dom Affomso [V]"20. Enquanto cronista-mor, Zurara estaria encarregado de ir reunindo materiais e provavelmente de ir redigindo o que seria a crónica geral do reino, mesmo que esta, tanto quanto se sabe, não tivesse visto a luz do dia senão já no século seguinte pela mão de Rui de Pina. Essa função primordial seria executada em simultâneo com a feitura do conjunto de textos em análise neste artigo, sobre os quais é possível detetar algumas indicações acerca das fontes reunidas pelo autor e do tratamento que lhes terá dado. Creio aliás, como tentarei demonstrar, que uma parte delas poderá ajudar a explicar a forma de algumas das crónicas.

6 A primeira tipologia consiste nos testemunhos orais, dos quais Zurara faz explícita menção em várias passagens da sua obra. É o caso da importância dos testemunhos dos Infantes D. Henrique e D. Pedro sobre a conquista de Ceuta ${ }^{21}$ e também de outros depoimentos que hoje se apresentam anónimos, mas de quem o cronista diz ter recebido "avisamento" 2 . No caso da elaboração da Crónica de D. Duarte de Meneses é bem possível que o peso dos testemunhos orais tenha sido ainda mais significativo, uma vez que Zurara esteve cerca de um ano no Magrebe (partiu em $1467^{23}$ ), tendo tido certamente a oportunidade de entrevistar muitos dos que conheceram e acompanharam o capitão de Alcácer nas suas lides bélicas. 
7 Essa estadia podia até ter permitido o contacto com algum tipo de documentação que não se encontraria na Torre do Tombo ou noutras instituições com sede em Lisboa e que albergavam arquivos potencialmente interessantes, como é o caso da Casa de Ceuta. Numa passagem da crónica em honra de D. Duarte de Meneses, Zurara alude à estratégia utilizada pelo capitão para controlar as aldeias dos vales contíguos a Alcácer. A certa altura, D. Duarte logrou que essas aldeias lhe pagassem tributo, especificando o cronista que os moradores de uma determinada terra ao "tempo que eu screuya esta storea eram trezentos casados e mais os que pagauam tributo" 24 . Sabendo que se trata de um mero indício que apenas permite avançar suposições, é pelo menos lícito colocar a possibilidade de Zurara ter consultado uma espécie de arrolamento desses vizinhos, talvez guardado no paço do capitão de Alcácer, local a partir de onde se exercia a autoridade sobre as terras em redor da praça. 0 mesmo se diga relativamente a uma passagem da crónica dedicada a D. Pedro de Meneses. Reportando-se às despesas efetuadas pelo capitão aquando da estadia na cidade dos Infantes D. Henrique e D. João, Zurara afirma que achou "per seus lyvros" - isto é, provavelmente um registo contabilístico da casa de D. Pedro de Meneses que a despesa com carnes e dádivas subiu a 6756 dobras ${ }^{25}$.

8 As fontes mencionadas mais frequentemente são, porém, escritos já compilados e trabalhados, e nos quais Zurara se baseou para elaborar a sua redação ${ }^{26}$. É o caso de referências anónimas como "aquelles que os feitos de Çeepta escreverão"27, ou "alguuns screuerom em seus scriptos"28. Noutros casos, Zurara indica autores ou materiais específicos. Na Crónica da Guiné refere por três vezes "huu Affomso cerueira que esta estorya primeiramente quis ordenar" ${ }^{29}$, enquanto na Crónica de D. Duarte de Meneses cita um "livro dos feitos" de D. Fernando de Noronha, não aclarando, contudo, a utilização que dele terá feito ${ }^{30}$. Seja como for, esta última e pequena referência deve sublinhar a evidência de que muito do que foi escrito na época não chegou até ao presente ${ }^{31}$. É por isso plausível admitir a existência de outros textos, nomeadamente de proveniência nobiliárquica, que circulariam e podiam ter sido conhecidos e utilizados pelo autor em questão, mas cuja existência é totalmente obscura para a crítica moderna.

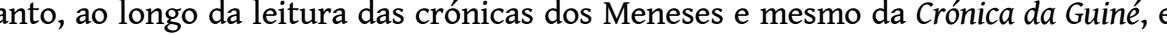
sobretudo nos longos ciclos em que são descritas em formas e termos algo repetitivos as cavalgadas, os ataques a aldeias ou operações de carácter anfíbio ao longo do litoral africano, fica-se com a ideia de que o autor terá recorrido a um tipo de documentação cuja utilização raramente explicita, mas que pode muito bem ter enformado grande parte destes capítulos. Refiro-me concretamente à correspondência que seria trocada entre o capitão e outros membros das guarnições norte-africanas e o reino ("cartas que ho comde escrevia a este rregno") ${ }^{32}$. Zurara terá utilizado esta correspondência para contar as diversas operações militares, numas circunstâncias compaginando hipoteticamente várias missivas sobre o mesmo episódio, noutras fazendo as devidas adaptações do conteúdo das epístolas ao tom que pretendia imprimir nas crónicas ${ }^{33}$. Quem enviaria essa correspondência, qual seria o seu volume, qualidade e que aproveitamento em concreto delas terá feito o cronista são questões que permanecerão provavelmente sem resposta.

Mesmo que hoje não tenhamos acesso a essas missivas, não se apresenta descabida a hipótese de que especialmente a correspondência do capitão fosse arquivada, assumindo como tal a forma de uma espécie de relatório enviado para o reino, dando conta dos problemas, das necessidades da praça mas também das expedições e dos feitos - até porque tanto o capitão como o resto da guarnição tinham todo o interesse em promover o valor dos seus esforços junto do monarca. Se enquadrados nestes moldes, os 
aparentemente repetitivos episódios bélicos narrados por Zurara poderão talvez ser mais bem compreendidos. Até porque, como o cronista fez questão de frisar, havia uma diferença entre os textos dedicados aos Meneses e aquela que seria a crónica geral, distinção que se refletia nos assuntos tratados em cada uma delas ${ }^{34}$. Por isso, a forma e o conteúdo das obras aqui em análise, assim como a seleção e a adaptação dos materiais a que o cronista recorreu ${ }^{35}$, é uma questão que tem que ver, entre outras coisas, com uma tradição estilística e com a mensagem que se pretendia transmitir com estas crónicas. Em primeiro lugar com o intento de serem espelhos de nobres, mas também com o intuito de serem um documento favorável a um dos grandes desígnios do reinado de D. Afonso V. Centremo-nos por ora no primeiro aspeto.

\section{2. "Espelhos de nobres"}

11 Considerar as obras de Zurara como espelhos de nobres significa enquadrá-las numa categoria artificial, inspirada na tradição literária dos espelhos de príncipes. Essas obras continham reflexões políticas e morais sobre o exercício do poder, e eram tidas como referências essenciais para os monarcas e príncipes europeus. Também em Portugal esse género literário proliferou ${ }^{36}$. Tendo presente os objetivos e características dessas obras, consideraremos as crónicas de Zurara enquanto espelhos de nobres na medida em que nelas se encontra um conjunto de ensinamentos e de exemplos através dos quais se transmitiam os valores e ideais pretensamente característicos da conduta nobiliárquica. Interessa por isso compreender que ideais são esses, e quais eram as implicações do modelo comportamental proposto para a vida do reino.

É preciso sublinhar que estas crónicas estavam pensadas para serem lidas e para "as orelhas dos ouvintes" ${ }^{37}$ do auditório cortesão. Há que fazer notar o facto de a corte régia ser, do ponto de vista social, um local de significativa heterogeneidade ${ }^{38}$. Apesar de ser um espaço aristocrático na medida em que aí se encontravam os dominantes na sociedade ${ }^{39}$, também é verdade que esses dominantes não eram apenas os que apelidamos de nobres ou fidalgos ${ }^{40}$. Nesse espaço social, os homens ligados ao desembargo ou à Igreja tinham um papel igualmente destacado, sendo que alguns homens e mulheres dentro desses diferentes grupos procuravam encontrar formas de progressão social que, não raras vezes, se deviam consubstanciar num fenómeno de nobilitação.

Em todo o caso, não deixa de ser visível a importância desempenhada pelos valores, gostos e comportamentos ditos nobiliárquicos, exercendo estes um certo poder de atração e de emulação para os diversos grupos aí presentes. No caso de que nos ocupamos neste artigo, a relevância atribuída aos modelos cavaleirescos é um reflexo notório da preponderância assumida pela ideologia e pelo simbolismo associado à nobreza. Quer para aqueles que eram reconhecidos como fidalgos, quer para os que almejavam esse estatuto, as referências guerreiras que no plano teórico definiam o lugar que a nobreza ocupava no edifício social afiguravam-se essenciais. Do ponto de vista da nobreza em geral, a emulação dos ideais da cavalaria significava o cumprimento das expectativas que recaiam sobre o grupo e, do ponto de vista individual, era igualmente a forma de serviço ao rei e de obtenção de honra primordiais no competitivo plano cortesão. Na ótica dos outros grupos aristocráticos não necessariamente pertencentes à nobreza, emular os comportamentos e símbolos cavaleirescos significava, por um lado, a realização de serviços sob a forma tida por uns como a mais honrada - a guerra - e evidenciava, por 
outro, uma tentativa daqueles grupos se associarem, através dos valores e das práticas, ao escol de topo na sociedade.

Os valores exaltados nas crónicas de Zurara refletem este contexto, pelo que não espanta a centralidade atribuída a todos os referenciais de natureza bélica. $\mathrm{E}$, nesse sentido, a virtude cardeal acaba por ser a fortaleza, também presente nas crónicas com o seu sinónimo ardideza. Ela significava a capacidade de demonstrar bravura, coragem e talento nos atos guerreiros. Tratava-se, enfim, da virtude que permitia concretizar a tríade que, segundo as Ordenações Afonsinas, definia os cavaleiros ${ }^{41}$ : "esforço, honra e poderio"42. Por isso, esta é a virtude mais exaltada ao longo das obras de Zurara. Era desde logo utilizada para elogiar alguns fidalgos: Gonçalo Vaz de Coutinho era "sabedor de guerra" e "ardido e forte"43; João Soares, "home de boa presemça e linhagem" e de "amtiga fidallguya" era também de "ardida natureza" ${ }^{4}$; D. Pedro de Meneses é louvado pela sua "gramde ardedeza" ${ }^{45}$; Afonso de Vasconcelos é retratado por "assy ardidamente cometya os Jmijgos assy os leuaua ante sy", tendo "estatura de corpo pequena" mas não lhe falecendo a "fortelleza do coraçom nem a nobreza e magnificancya e as outras uertudes" 46 .

15 A fortaleza enquanto virtude cardeal dos cavaleiros pode ser explicada por estar também, segundo Zurara, umbilicalmente ligada à obtenção de honra, o que, por sua vez, era algo próprio dos fidalgos ${ }^{47}$. A ideia do cronista é que somente os homens com passado - isto é, com "avoengas" - eram movidos à prática de grandes feitos, pois sobre eles pesava a responsabilidade de não envergonhar a linhagem. 0 peso da mácula que a vergonha pode trazer é, de resto, um tema recorrente nos textos dedicados à cavalaria - literários, didáticos ou legislativos -, assim como a própria importância da fortaleza ${ }^{48}$. A centralidade deste ideal (entendendo-o simultaneamente como demonstração de coragem e perícia nos atos miliares) encaixa naquilo que Richard W. Kaeuper chamou "a worship of demi-god prowess", considerando que a prática da violência, enquanto função e privilégio dos cavaleiros no esquema funcional da sociedade, era também a fonte essencial de honra ${ }^{49}$. Honra que, segundo Zurara, "he aquella uida em que os homeens uiuem pera sempre" ${ }^{50}$, ou seja, a fama de bom e de alguém que vive de acordo com o que dele é esperado.

Outras virtudes são, contudo, igualmente importantes, ainda que não se apresentem tão salientes numa primeira leitura dos textos. É o caso da lealdade, um ideal que vai ocupar uma importância crescente no esquema ideológico da cavalaria nos séculos XIV e XV como consequência da adaptação dos referenciais cavaleirescos à nova estruturação dos poderes típica dos estados modernos. A lealdade ao rei e ao reino poderia no limite implicar o sacrífico dos cavaleiros em prol de um bem maior, cujo exemplo mais representativo é a imolação de D. Duarte de Meneses para salvar D. Afonso V na serra do Benacofu ${ }^{51}$.

Outro aspeto também muito presente na época é a discussão da eficiência militar, para a qual aliás não contribuem apenas a fortaleza e a ardideza. São várias as passagens nas crónicas sobre Marrocos onde é salientada a necessidade de aliar estas virtudes a uma outra determinante e também de origem clássica: a prudência. Esta questão é particularmente pertinente no caso dos capitães. Depois de mais uma demonstração dos seus ímpetos guerreiros, D. Pedro de Meneses é alertado por Gonçalo Nunes que a sua função implicava que "primeiro sejaes boom capitão e depois bõo cavaleiro", recordando que, como afirmava Vegécio no "llyvro da Arte da Cavalaria", aos príncipes e aos "rregedores da oste pertemçe mais a prudemçia que a cada hu dos outros cavalleiros" ${ }^{52} .0$ que estava em causa era o cumprimento dos objetivos militares de cada operação, para o 
qual os ímpetos bélicos dos cavaleiros eram determinantes mas tinham forçosamente de ser coordenados com prudência, disciplina e respeito pela cadeia de comando. Essa discussão está exemplarmente demonstrada em duas passagens. Numa delas, D. Duarte de Meneses repreende alguns cavaleiros da guarnição de Alcácer dizendo-lhes que apesar de eles quererem atuar como "nobres e uallentes caualleyros e homeens dignos de grande louuor" deveriam ter "boa regra" e "disciplina" para que a praça não ficasse em risco e, com ela, a "honra delRey nosso Senhor". Segundo o capitão, isso não podia ser posto em causa apenas para deleite de alguns que queriam "nouos titollos dardimento e de fortelleza" ${ }^{53}$. A outra situação passa-se com o escudeiro Gonçalo de Sintra. Tendo recebido o comando de uma caravela com a missão de ir à Guiné, o escudeiro criado do Infante D. Henrique, motivado pela cobiça de "cobrar fama", decidiu fazer um desvio com destino à ilha de Arguim, pois a curta distância poderiam capturar alguns cativos. A expedição não correu bem e, no meio de uma emboscada, Gonçalo de Sintra optou por perder a vida de forma heroica. Apesar de Zurara elogiar a bravura do escudeiro no momento capital, não deixa, porém, de elencar as lições que os fidalgos deveriam retirar da atitude irresponsável de Gonçalo. Entre conselhos mais práticos para a condução da guerra ao longo do litoral africano, outras lições destacam-se como mandamentos gerais para a prática guerreira, como por exemplo não contrariar ordens superiores, assim como confiar nos conselhos dos homens que vão na companhia - regras que, para seu próprio prejuízo, Gonçalo de Sintra não cumpriu ${ }^{54}$.

O espírito didático também está presente nas sugestões de leituras que se encontram ao longo das crónicas. Neste caso, obras do período clássico mas que sobreviveram e foram sucessivamente readaptadas no período medieval, como o tratado de Vegécio ou o relato de Júlio César ${ }^{55}$. D. Duarte de Meneses é apresentando por Zurara como sendo um "excelente capitão", forte e prudente, julgado positivamente e comparado a um novo Marco Fúrio Camilo por aqueles que tinham autoridade para isso, isto é, os que "as cronicas romãas auyam lijdas" ${ }^{\text {. }}$. Está implícito, portanto, que os fidalgos deviam conhecer estes textos, que formariam parte da sua cultura militar ${ }^{57}$ e cuja leitura era aconselhada pelo próprio rei D. Duarte ${ }^{58}$, quer em tempo de paz, quer em tempo de guerra 59 .

Todos estes exemplos, assim como o próprio discurso de D. Duarte de Meneses a repreender os fidalgos da guarnição (certamente ficcionado por Zurara, mas perfeitamente normal na lógica da recriação de arengas ou discussões militare ${ }^{60}$ ), destinavam-se, portanto, a transmitir um conjunto de mensagens ${ }^{61}$. Os fidalgos deviam procurar ser bons cavaleiros, e isso significava serem fortes e ardidos para enfrentarem situações de risco, mas simultaneamente leais, obedientes, cumpridores da hierarquia de comando e dotados de alguma cultura teórica sobre a guerra. De tudo isso retiravam honra, que era, segundo Zurara, a recompensa própria para a fidalguia. Ora, esta retórica é compaginável com outros textos escritos na época, e que demonstram que as mensagens transmitidas pelo cronista-mor se enquadram num esquema bem definido $\mathrm{e}$ genericamente aceite pela sociedade cortesã. Acerca da centralidade da fortaleza, dizia o Infante D. João no seu parecer sobre a continuidade da guerra em África escrito em torno de 1430 que "os que em nosso estado vyuem não podem ser quanto ao deste mundo ditos bons se honrra de Cauallaria non alcanção", a qual só se pode obter na guerra e através de um feito "dessarezoado e perigoso" ${ }^{2}$. Contrariamente ao siso, que dizia que não se devia deixar o certo pelo incerto, a cavalaria significava, aos olhos do Infante, a capacidade de correr riscos para alcançar grandes feitos. Essa ideia de esforço está também presente na 
obra do rei D. Duarte, defendendo o monarca que os que andavam em "feitos de cavalaria" tinham de se expor a todos os perigos e trabalhos necessários ${ }^{63}$.

A questão que se coloca agora é saber qual a pertinência deste discurso. Qual era de facto o interesse da coroa em patrociná-lo? E que implicações tinha este quadro de valores para as fileiras aristocráticas? Pela perspetiva dos monarcas enquanto regedores do reino, há que ter presente a necessidade de manter um braço armado devidamente preparado e capaz de responder a situações de risco. Por isso, alimentar as capacidades bélicas da fidalguia afigurava-se algo de essencial para manter o reino em segurança, e esses argumentos estão presentes, por exemplo, na Crónica da Tomada de Ceuta. Escrevendo por volta de 1449-1450, um dos argumentos colocados por Zurara na boca de D. João I a favor da manutenção da cidade é justamente para que "os boos homeens de meus rregnos nom ajam rrezam desqueçer o virtuoso exerçiçio das armas" ${ }^{64}$. Também a crónica dedicada ao Infante D. Fernando apresenta as mesmas causas a motivar a expedição sobre Tânger em 143765; curiosamente, e pela sua própria pena, o rei D. Duarte salientava que esta era uma das razões pelas quais decidia organizar a expedição cujo final desastroso levou ao cativeiro de seu irmão ${ }^{66}$. Além disso, a discussão sobre as virtudes essenciais dos cavaleiros - fortaleza, prudência, lealdade, assim como a questão da eficiência militar estava na ordem do dia em várias latitudes da Cristandade ${ }^{67}$.

21 E que implicações tinha este quadro de valores para as fileiras aristocráticas? Como se tentou demonstrar, as crónicas de Zurara representam uma visão partilhada por alguns setores do entorno cortesão, servindo como referência de comportamentos e ideais a vários quadrantes da aristocracia: tanto à nobreza cortesã como a linhagens menos relevantes no seio do grupo, ou ainda a homens provenientes do desembargo ou de setores da chamada aristocracia urbana. Se a coroa decidiu conquistar e manter praças no Norte de África, vemos enstanciarem com maior ou menor regularidade nesses locais homens pertencentes a esses vários estratos aristocráticos ${ }^{68}$. Todos percebiam que a participação neste teatro de guerra era fundamental para manter o prestígio da estirpe e procurar honras e benesses, e, nesse sentido, lograr que os seus nomes fossem inscritos nas crónicas de Zurara significava algo de muito importante. No fundo, esta circunstância reflete um problema mais lato. Por um lado, os referenciais cavaleirescos contribuíam para a coesão do grupo aristocrático, fornecendo-lhe elementos de identificação e ligação. Por outro lado, a cavalaria era também uma forma de renovação da aristocracia, estabelecendo cânones de entrada de novos elementos no grupo.

Para todos eles, figurar nas crónicas de Zurara tinha várias implicações positivas. Num sentido mais lato, a escrita assegurava a memória e a perenidade dos feitos que haviam protagonizado. Como retoricamente perguntava D. Afonso V numa carta ao cronista, o que seria de Aquiles se Homero não tivesse escrito os seus feitos ${ }^{69}$ ? E o que se saberia dos feitos dos romanos, que tanto inspiravam os homens deste tempo, se Tito Lívio os não tivesse narrado ${ }^{70}$ ? Mas para além disto, e num plano mais imediato, figurar nestas crónicas significava que, no auditório cortesão onde estes textos eram conhecidos, os nomes dos cavaleiros eram repetidos e dados a conhecer enquanto fortes e ardidos, com todos os benefícios que se poderiam esperar desse reconhecimento ${ }^{71}$. Daí que a maneira como certos personagens figurariam na narrativa - como heróis ou como fracos - ou até se teriam ou não lugar no texto afigurava-se algo de fundamental na lógica competitiva que pautava a relação entre os setores aristocráticos no círculo cortesão ${ }^{72}$. Competição $\mathrm{e}$ rivalidade de que Zurara dá vários exemplos: as intrigas e armadilhas movidas por D. Leonor de Meneses ao seu meio-irmão D. Duarte, diminuindo a sua importância perante o 
rei D. Duarte ${ }^{73}$; as invejas e maledicência suscitadas pela ascensão de D. Duarte de Meneses ainda na sua juventude, em Ceuta ${ }^{74}$; ou ainda a "capital" inimizade que existira entre Martim de Távora e Gonçalo Vaz Coutinho ${ }^{75}$. Todavia, não deixa de ser notório que a coroa acabe por, em última análise, patrocinar esse esquema competitivo com o benefício de, através dele, poder estabelecer algumas regras e pressupostos para manipular a estruturação da aristocracia ${ }^{76}$. Neste caso, os modelos cavaleirescos acabam por ser a linguagem através da qual se expressa esta dinâmica: bom cavaleiro é aquele que reúne as virtudes já descritas, em causas favoráveis ao rei e ao reino, e que merece ser honrado por isso.

Zurara dá conta da importância séria que os seus textos tinham nesta lógica competitiva quando confessa que "ainda eu bem nom tomo a pena na mãao pera screuer. Ja começam de condanar mjnha obra": uns porque temiam que nada se dissesse sobre eles, outros porque receavam ver o seu papel diminuído ${ }^{77}$. Fosse como fosse, este contexto explica o por vezes longo e até enfadonho elencar de nomes que se encontra ao longo das obras - e que Zurara por vezes interrompe, seja porque nem todos os nomes foram apontados ${ }^{78}$, seja para "nom causar fastyo"79. Certo é que D. Afonso V reconhece que crónicas de Zurara teriam sido fundamentais para o monarca recompensar devidamente os trabalhos de alguns fidalgos que serviram em África: “depoys que eu vi a coronica que vos delles escreuestes: a muytos fiz onrra e merçe com milhor vontade por ser çerto dalguns boons feytos que la fizeraõ"80.

24 Estes dois aspetos (a memória glorificada da linhagem e os dividendos retirados a curto / médio prazo) andam de mãos dadas ${ }^{81}$, como fica bem patente nas palavras de $\mathrm{D}$. Afonso V. Por isso mesmo, a aristocracia procurou valorizar o seu comprometimento ao projeto guerreiro português no Norte de África. Zurara reconhece que D. Leonor de Meneses foi uma das mais entusiastas promotoras junto de D. Afonso V para que se empreendesse a redação da crónica em honra de seu pai ${ }^{82}$. Tal movimentação, compaginada com a vontade de D. Pedro em recuperar os títulos que pertenciam à linhagem antes da crise de 1383-1385 ${ }^{83}$, ou com a criação do panteão na Igreja da Graça em Santarém ${ }^{84}$, fazem com que se possa vislumbrar um claro projeto simbólico levado a cabo por esta linhagem. De resto, o próprio texto do epitáfio tumular de D. Pedro de Meneses enquadra-se no conteúdo da crónica em seu louvor, frisando-se os méritos guerreiros deste cavaleiro e o facto de ter governado Ceuta durante 22 anos, "huma soo em africa per xpistãos possuida" 85 .

Mas se os Meneses são o exemplo mais notório e citado, a verdade é que outros se podem juntar. Nos epitáfios tumulares da nobreza portuguesa podem-se contar várias referências explícitas à participação dos sepultados na guarnição de Ceuta: desde indivíduos recordados por terem participado na conquista ${ }^{86}$, outros por aí terem sido armados cavaleiros ${ }^{87}$, e outros ainda por aí terem perecido ${ }^{88}$. Por tudo isto, fica patente uma clara coincidência entre os comportamentos e os modelos de autorrepresentação utilizados pela aristocracia e os ideais propostos nas crónicas de Zurara. É possível então detetar uma notória circularidade de ideais e comportamentos que fazem dos textos em análise neste artigo, na sua forma e estilo, algo de essencial para compreender o mundo aristocrático do século XV, em particular da esfera cortesã. Ao definirem concretamente o que deveria caracterizar o comportamento dos nobres, estes textos figuravam assim enquanto 'espelhos', definindo não só as referências comportamentais dos nobres propriamente ditos, mas definindo também os moldes através dos quais aqueles que almejavam atingir esse estatuto social poderiam operar a sua ascensão. 
26 No entanto, para além dos valores que defendiam e que eram genericamente aceites neste meio, a verdade é que estes textos eram também documentos a favor de ideias e projetos acalentados ao longo do reinado de D. Afonso V, mas que não eram encarados com unanimidade - como sempre sucede, de resto, mas que não se torna tão evidente caso se fique apenas pela leitura das obras de Zurara.

\section{Documentos a favor de um "projeto"}

Ao ler as obras de Zurara, fica-se com a impressão de que o cronista se esforça por tentar demonstrar que havia uma mobilização unânime no reino em torno do esforço militar em Marrocos (salvo os medos e hesitações dos "néscios" antes do ataque a Ceuta), e de que este esforço tinha acima de tudo um caráter justo e até sacralizado em virtude de ser consagrado como tal pelas bulas papais. No entanto, havia na sociedade portuguesa vozes dissonantes, o que faz destas crónicas e da utilização que delas foi feita um dos documentos a favor de um plano de intenções perseguido ao longo do reinado de D. Afonso $\mathrm{V}^{89}$. Plano gizado e perseguido pelo próprio monarca, mas também por um dos principais personagens das narrativas de Zurara: o Infante D. Henrique ${ }^{90}$. Importa como tal ter presentes quais eram os principais argumentos contra o esforço de guerra no Magrebe, e de que maneira as crónicas de Zurara foram utilizadas e fazem parte de uma 'propaganda' levada a cabo pela coroa portuguesa com o intuito de demonstrar a valia e a singularidade da gesta guerreira lusitana naquela região.

Os manifestos contra as investidas em Marrocos são da autoria de membros do Conselho Régio. Homens provenientes das mais altas esferas nobiliárquicas e que, ao longo do século XV, foram chamados a dar a sua opinião acerca dos rumos da política do reino, não se demitindo, nessas circunstâncias, de se manifestarem contra ou com algumas reservas face a este projeto ${ }^{91}$. Assim o fez o conde de Barcelos na década de 1430, referindo-se ao exagerado custo humano e material provocado pelo "dano de çepta" ${ }^{22}$, mas também o conde de Arraiolos, para quem a honra de um feito de armas por si só de pouco valia, dizendo que os que assim pensavam rapidamente perceberiam que "honrra sem proveito prestava pouqo"93. Na década de 1460 surgem outros pareceres que colocam reservas a novas investidas em Marrocos, baseando-se em argumentos que hoje apelidaríamos de 'pragmáticos' ou 'realistas'. É o caso do marquês de Vila Viçosa, que dizia "sentir tão pouco da guerra de Afriqua", desconfiando dos que na corte defendiam esta via por "dezejo de maior gloria e de cobiça". Frisava, contudo, que não deixaria de servir o monarca "se lla sempre fordes, como sempre fiz"94. Já o condestável D. Pedro aconselhava o monarca a dedicar-se ao "pacifico regimento da cousa pubrica", não acreditando na viabilidade da conquista de África e da conversão do continente ao Cristianismo ${ }^{95}$.

Em síntese, os pareceres contra a continuação da guerra em Marrocos, não deixando de sublinhar o seu caráter justo e até piedoso, manifestam-se contra sobretudo por razões práticas, tais como o imenso custo humano e material e a impossibilidade estratégica de o reino de Portugal conseguir por si só derrotar o poderio muçulmano em África. Daí que, não raras vezes, estas personalidades aconselhem o monarca a procurar disferir um golpe contra o Islão não em África mas sim em Granada, ainda que este cenário de guerra implicasse um acordo com Castela.

30 Face a estas posições, parece ter havido um esforço retórico e 'propagandístico' da coroa para sustentar o seu plano guerreiro no Norte de África, do qual as crónicas de Zurara são 
peça-chave, mas, ainda assim, não únicas ${ }^{96}$. Se esses textos se propunham relatar as façanhas portuguesas no Magrebe e nas explorações do litoral africano, apresentando esse esforço como justo, meritório e honrado, não se pode deixar de enquadrar num espírito semelhante a redação da crónica em memória do Infante D. Fernando, apresentando-o primeiro como um verdadeiro cruzado, "Armado este Ifante do sinal da †", e "despoendo se a todo periigo e trabalho pola santa fe, sob guarda do alferez de Jhesu Christo Sa Miguel, que em seu estendarte levava pintado" ${ }^{97}$ e, depois, como modelo de mártir pela fép ${ }^{98}$. Além dos textos, as cerimónias públicas tinham igualmente o poder de difundir estas mensagens. A mesma crónica dedicada ao Infante D. Fernando relata a partida para Tânger envolvida num ambiente de festa e solenidade, com missas e procissões, no meio das quais se destaca a entrega da absolvição pela bula de cruzada, o exibir da bandeira de cruzada e, também, a já referida capa com o sinal da cruz pelas costas do Infante e de todos os que partiam na armada ${ }^{99}$. Tanto quanto se sabe, este tipo de manifestações ter-se-á repetido com alguma frequência ao longo da centúria. Um documento de 1488 contém as instruções dadas por D. João II às autoridades de Lisboa sobre como pregar a nova bula de cruzada recebida. Ordenava o rei que se organizasse uma procissão de receção do documento desde as portas da cidade até à Sé, indo nela "tocadores de harpas, órgão e trombeta", com as ruas limpas e ornamentadas. 0 dia marcado para a pregação seria também feriado, para que as gentes da cidade e do seu termo pudessem presenciar a cerimónia e ser envolvidas pelo ambiente de fervor ${ }^{100}$.

31 Havia, portanto, da parte da coroa e dos círculos favoráveis ao esforço militar no Norte de África, uma clara vontade de difundir um espírito proselítico em torno da guerra frente ao Islão, do qual, como já se referiu, as crónicas de Zurara são uma entre várias peças ${ }^{101}$. Mas é também importante fazer notar que estes elementos propagandísticos tiveram uma difusão internacional, certamente com o intuito de afirmar o reino português e demonstrar a sua potência e valor. Desde logo, duas das crónicas assinadas por Zurara foram traduzidas para latim, pois, como explicita o autor no texto dedicado a D. Pedro de Meneses, a intenção era que "fossem manyfestos a todo conhecimento de toda a nobreza da cristamdade"102. As letras, a juntar à imagem (as tapeçarias de Pastrana), à música (uma peça encomendada por D. Afonso V para celebrar a conquista de Arzila) e à correspondência com outros príncipes europeus (como uma carta enviada de Marrocos para o duque da Borgonha, posteriormente traduzida para francês e utilizada pelos cronistas do norte da Europa), fazem com que se possa falar, segundo Rita Costa Gomes, de uma constelação de trabalhos artísticos e culturais para celebrar a experiência das guerras de expansão no Norte de África ${ }^{103}$. Expressões a que não ficariam alheios nem portugueses nem estrangeiros. Os representantes do imperador Frederico III testemunharam a referência ao martírio do Infante D. Fernando numa arenga pública e a comoção geral que tal menção terá provocado entre os que assistiam à pregação na rua ${ }^{104}$. $\mathrm{Na}$ mesma linha, e segundo Zurara, D. Afonso $\mathrm{V}$ faria ler, perante os estrangeiros presentes na corte, algumas cartas onde se relatavam expedições bem-sucedidas no Magrebe ${ }^{105}$. A tudo isto também não será estranha a frequência com que cavaleiros de outras paragens instanciaram nas praças magrebinas, vendo nas pontas avançadas detidas pelos portugueses locais privilegiados para a obtenção de honra. Zurara é um dos que testemunha esta realidade ${ }^{106}$. 


\section{Conclusões} interpretadas segundo um contexto específico, considerando desde logo o facto de três delas - à exceção da Crónica da Tomada de Ceuta, com os devidos matizes - formarem um plano distinto da Crónica Geral do Reino. Neste sentido, a forma e o estilo das obras devem ser enquadradas sob várias perspetivas. Em primeiro lugar, num género literário cavaleiresco que estava muito em voga na época e cujos valores e características tinham já, no século XV, uma longa tradição ${ }^{107}$. Um género onde pontifica a aventura e onde são louvados audazes e bravos cavaleiros, certamente para deleite e entretenimento dos auditórios cortesãos.

Mas, para além deste plano, as crónicas de Zurara também tinham outras implicações. Eram desde logo espelhos de nobres na medida em que nelas se encontravam relatos exemplares - para o bem mas também para o mal - que lhes conferiam um estatuto didático e de difusão de um quadro de valores e comportamentos tidos como ideais, e cuja emulação seria fonte de honra. Propunha-se fundamentalmente que os cavaleiros fossem fortes e ardidos, leais e prudentes, tudo com o fito essencial de obterem a eficiência militar que deles fazia, teoricamente, o braço armado indispensável à segurança e à estabilidade do reino. Figurar nas crónicas de Zurara como bom cavaleiro era forma de honrar a linhagem com a imortalidade da escrita, mas era também, num plano mais imediato, uma via para obter recompensas honoríficas e materiais. A escrita do cronista acabava por ser, como ele próprio não deixava de sublinhar, uma de entre as várias arenas de competição aristocrática na esfera da corte régia, traduzindo a importância da mundividência cavaleiresca enquanto forma de coesão do grupo aristocrático, mas também como meio de progressão social para os que desejavam aceder à categoria nobiliárquica.

multaneamente, as crónicas celebraram, em conjunto com outras peças artísticas e cerimónias públicas, a gesta guerreira portuguesa em África, retratando-a como honrada e justa e como um serviço que o reino fazia em prol de Deus e da Cristandade. Um sacrífico a que os cavaleiros portugueses eram convidados, sendo aliás uma sugestão que pretenderia certamente convencer ou silenciar as vozes que se erguiam contra o conflito, vendo-o como interminável, injusto ou infrutífero - sem sucesso, no entanto, considerando a longevidade da presença portuguesa em Marrocos. A força e a honra do reino eram também proclamadas junto de outros potentados da Cristandade, esforço que certamente presidiu à intenção de traduzir algumas das crónicas de Zurara para latim.

Através de todos estes prismas e matizes, sem dúvida que as obras de Zurara ganham muito em riqueza e complexidade. Aquilo que, numa leitura mais superficial ou menos precavida, poderá soar a repetitivo, enfadonho ou a uma exagerada glorificação retórica poderá ser, afinal, o reflexo de algo muito mais vivo e complexo. 


\section{BIBLIOGRAFIA}

Fontes impressas

ÁLVARES, Frei João - Trautado da Vida e Feitos do muito Vertuoso S.or Ifante D. Fernando. Ed. Adelino de Almeida Calado. Coimbra: Universidade de Coimbra, 1960, vol. I.

DOCUMENTOS DO ARQUIVO HISTÓRICO da Câmara Municipal de Lisboa - Livros de Reis. Lisboa: Câmara Municipal de Lisboa, 1959, vol. 3.

DOM DUARTE - Leal Conselheiro. Ed. Maria Helena Lopes de Castro. Lisboa: Imprensa Nacional Casa da Moeda, 1998.

DOM DUARTE - Livro da Ensinança de Bem Cavalgar Toda a Sela que fez El-Rey Dom Eduarte. Ed. Joseph M. Piel. Lisboa: Imprensa Nacional Casa da Moeda, 1986.

DOM DUARTE - Livro dos Conselhos de El-rei D. Duarte (Livro da Cartuxa). Ed. João José Alves Dias e A. H. de Oliveira Marques. Lisboa: Estampa, 1982.

Leonor de Portugal, Imperatriz da Alemanha: diário de viagem do Embaixador Nicolau Lanckman de Valckenstein. Ed. Aires de Nascimento. Lisboa: Cosmos, 1992.

MONUMENTA HENRICINA. Ed. António J. Dias Dinis. Coimbra: Comissão Executiva das Comemorações do V Centenário da Morte do Infante D. Henrique, 13 vols.

ORDENAÇÕES AFONSINAS. Lisboa: Fundação Calouste Gulbenkian, 1998, Livro I.

ZURARA, Gomes Eanes de - Crónica da Tomada de Ceuta por el rei D. João I. Ed. Francisco Maria Esteves Pereira. Lisboa: Academia das Ciências de Lisboa, 1915.

ZURARA, Gomes Eanes de - Crónica do Conde D. Duarte de Meneses. Ed. Larry King. Lisboa: Faculdade de Ciências Sociais e Humanas - Universidade Nova de Lisboa, 1978.

ZURARA, Gomes Eanes de - Crónica dos feitos notáveis que se passaram na conquista de Guiné por mandado do infante D. Henrique. Ed. Torquato de Sousa Soares. Lisboa: Academia Portuguesa da História, 1997, 2 vols.

Estudos

AGUIAR, Miguel - Ideologia Cavaleiresca em Portugal no Século XV. Porto: Universidade do Porto, 2016. Dissertação de Mestrado.

BERTOLI, André - O Cronista e o Cruzado: a revivescência do Ideal Cavaleiresco no Outono da Idade Média Portuguesa (Século XV). Curitiba: Universidade de Curitiba, 2009. Dissertação de Mestrado.

BERTOLI, André - "Modelos de ação bélica na Crônica de D. Duarte de Meneses - Texto, Contexto e Representação”. Mirabilia 15 (2012/2), pp. 171-201.

BUESCU, Ana Isabel - “Um Discurso sobre o Príncipe: a "pedagogia especular” em Portugal no século XVI”. Penélope 17 (1997), pp. 33-50.

BRAGANÇA, José de - "Introdução". In ZURARA, Gomes Eanes de - Crónica da Guiné. Porto: Livraria Civilização, 1937, vol. I, pp. I-XLV.

CAMPOS, Nuno Silva - D. Pedro de Meneses e a construção da casa de Vila Real (1415-1437). Lisboa: Colibri/CIDEHUS, 2004. 
COELHO, Maria Helena da Cruz - “Aristocracia Vilã”. in COELHO, Maria Helena da Cruz e HOMEM, Armando Luís de Carvalho (coord.) - Portugal em Definição de Fronteiras. Lisboa: Presença, 19, pp. 253-260.

CURTO, Diogo Ramada - “A Literatura e o Império: entre o espírito cavaleiresco, as trocas da corte e o humanismo cívico”. in BETHENCOURT, Francisco e CHAUDHURI, Kirti (dir.) - História da Expansão Portuguesa. Lisboa, Círculo de Leitores, 1998, vol. I, pp. 434-454.

DINIS, A. J. Dias - Vida e Obras de Gomes Eanes de Zurara. Lisboa: Agência Geral das Colónias, 1949, vol. I.

DUARTE, Luís Miguel - “Os melhores da terra (um questionário para o caso português)”. in BARATA, Filipe Themudo (ed.) - Elites e redes clientelares na Idade Média: problemas metodológicos. Lisboa: Colibri e CIDEHUS-EU, 2001, pp. 91-106.

DUARTE, Luís Miguel - Ceuta, 1415: Seiscentos anos depois. Lisboa: Livros Horizonte, 2015.

FERNANDES, Adriano - A Crónica do Conde D. Duarte de Meneses de Gomes Eanes de Zurara: estudo histórico-cultural e edição semidiplomática. Vila Real: Universidade de Trás-os-Montes e Alto Douro, 2007, 2 vols. Tese de Doutoramento.

FIGUEIREDO, Albano - O ideal de cavalaria na crónica da Tomada de Ceuta de Gomes Eanes de Zurara. Coimbra: Universidade de Coimbra, 1996. Dissertação de Mestrado.

FIGUEIREDO, Albano - "O narrador e o herói na Crónica da Tomada de Ceuta de Gomes Eanes de Zurara". in Figura: Actas do II Colóquio da Secção Portuguesa da Associação Hispânica de Literatura Medieval. Faro: Faculdade de Ciências Humanas e Sociais da Universidade do Algarve, 2001, pp. 89-109.

FIGUEIREDO, Albano - A Crónica Medieval Portuguesa: génese e evolução de um género (sécs. XIV-XV). A dimensão estética e a expressividade literária. Coimbra: Universidade de Coimbra, 2005. Tese de Doutoramento.

FIGUEIREDO, Albano - "Viagem, cavalaria e conquista na Crónica de Guiné de Gomes Eanes de Zurara". in Modelo: Actas do V Colóquio da Secção Portuguesa da Associação Hispânica de Literatura Medieval. Porto: Departamento de Estudos Portugueses e de Estudos Românicos - Faculdade de Letras da Universidade do Porto, 2005, pp. 25-33.

FONSECA, Luís Adão. “Uma carta do Condestável Dom Pedro sobre a política marroquina de D. Afonso V”. Revista da Faculdade de Letras: História 1ª́rie, vol. I (1970), pp. 83-96.

GAUCHER, Elisabeth - La Biographie Chevaleresque: typologie d'un genre (XIII-XV siècle). Paris: Honoré-Champion Éditeur, 1994.

GIBELLO BRAVO, Víctor - La Imagen de la Nobleza Castellana en la Baja Edad Media. Cáceres: Universidad de Extremadura, 1995.

GOMES, Rita Costa - A Corte dos Reis de Portugal. Lisboa: Difel, 1995.

GOMES, Rita Costa - "Zurara and the Empire: Reconsidering Fifteenth-century Portuguese Historiography”. Storia della storiografia 47 (2005), pp. 56-89.

KAEUPER, Richard W. - Chivalry and Violence in Medieval Europe. Oxford: Oxford University Press, 1999.

KING, Larry - "Introdução", in ZURARA, Gomes Eanes de - Crónica do Conde D. Duarte de Meneses. Ed. Larry King. Lisboa: Faculdade de Ciências Sociais e Humanas - Universidade Nova de Lisboa, 1978, pp. 21-40.

LEITE, Duarte - Acerca da “Cronica dos Feitos de Guinee”. Lisboa: Bertrand, 1941. 
MONTEIRO, João Gouveia - “A Cultura Militar da Nobreza na primeira metade de Quatrocentos”. Revista de História das Ideias 19 (1997), pp. 195-229.

MONTEIRO, Nuno Gonçalo - O Crepúsculo dos Grandes: a Casa e o Património da Aristocracia em Portugal (1750-1832). Lisboa: Imprensa Nacional Casa da Moeda, 2003.

MORSEL, Joseph - L'aristocratie médiévale. Paris: Armand Colin, 2004.

PIMPÃo, Álvaro Júlio da Costa - A "Crónica dos feitos de Guinee": as minhas "teses" e as "teses" de Duarte Leite. Coimbra: Livraria Gonçalves, 1941.

PIMPÃo, Álvaro Júlio da Costa - Escritos Diversos. Coimbra: Universidade de Coimbra, 1972.

PONTES, Luís Filipe - Do mundo da corte ao mundo da memória. Subsídios para o estudo da mentalidade cavaleiresca da nobreza portuguesa, 1400-1521. Lisboa: Universidade Nova de Lisboa, 2008.

Dissertação de Mestrado.

RODRÍGUEZ VELASCO, Jesús - El Debate sobre la Caballería en el siglo XV: la Tratadística Caballeresca Castellana en su marco Europeo. Salamanca: Junta de Castilla y León, 1996.

ROSA, Maria de Lurdes - O Morgadio em Portugal: Sécs. XIV-XV. Lisboa: Estampa, 1995

ROSA, Maria de Lurdes - "Mortos - "tidos por vivos": o Tribunal Régio e a capacidade sucessória das "Almas em Glória" (Campanhas Norte- Africanas, 1472-c. 1542)". Anais de História de Além-Mar 6 (2005), pp. 9-46.

ROSA, Maria de Lurdes - "Velhos, novos e mutáveis sagrados...um olhar antropológico sobre as formas "religiosas" de percepção e interpretação da conquista africana (1415-1521)". Lusitânia Sacra 18 (2006), pp. 13-85.

RUSSELL, Peter - Henrique, o Navegador. Lisboa: Horizonte, 2004.

SARAIVA, António José - História da Cultura em Portugal. Lisboa: Jornal do Fôro. 1950, 2 vols.

SARAIVA, António José - O Crepúsculo da Idade Média em Portugal. Lisboa: Gradiva, 1998.

SERRÃO, Joaquim Veríssimo - Cronistas do Século XV posteriores a Fernão Lopes. Lisboa: Instituto de Cultura e Língua Portuguesas, 1989.

SOUSA, Bernardo Vasconcelos e - "Linhagem e Identidade Social na Nobreza Medieval Portuguesa (Séculos XIII-XIV) ”. Hispania vol. LXVII, nº 227, pp. 881-898.

TAYLOR, Craig - "English Writings on Chivalry and Warfare during the Hundred Years War". in CROSS, Peter e TYERMAN, Christopher (dir.) - Soldiers, Nobles and Gentlemen: Essays in Honour of Maurice Keen. Woodbridge: Boydell, 2009, pp. 64-84.

TAYLOR, Craig - "Military Courage and Fear in the Late Medieval French Chivalric Imagination". Cahiers de Recherches Médiévales et Humanistes 24 (2012), pp. 129-147.

TAYLOR, Craig - Chivalry and the Ideals of Knighthood in France during the Hundred Years War. Cambridge: Cambridge University Press, 2013.

\section{NOTAS}

1. ZURARA, Gomes Eanes de - Crónica do Conde D. Duarte de Meneses. Ed. Larry King. Lisboa: Faculdade de Ciências Sociais e Humanas - Universidade Nova de Lisboa, 1978, p. 234.

2. GOMES, Rita Costa - A Corte dos Reis de Portugal. Lisboa: Difel, 1995, pp. 62-108. 
3. Como por exemplo desmantelar peças de artilharia ou recolher lenha. A descrição deste assédio encontra-se em ZURARA, Gomes Eanes de - Crónica do Conde D. Duarte de Meneses, pp. 201-234.

4. Tendo sido motivo para uma certa menorização do cronista, principalmente em comparação com o seu predecessor, Fernão Lopes. Vejam-se as sínteses desta leitura crítica em DINIS, A. J. Dias - Vida e Obras de Gomes Eanes de Zurara. Lisboa: Agência Geral das Colónias, 1949, vol. I pp. 51-60; KING, Larry - "Introdução". in ZURARA, Gomes Eanes de - Crónica do Conde D. Duarte de Meneses, pp. 26-27; SERRÃO, Joaquim Veríssimo - Cronistas do Século XV posteriores a Fernão Lopes. Lisboa: Instituto de Cultura e Língua Portuguesas, 1989, pp. 35-37; e sobretudo em DUARTE, Luís Miguel - Ceuta, 1415: Seiscentos anos depois. Lisboa: Livros Horizonte, 2015, pp. 33-44.

5. SARAIVA, António José - História da Cultura em Portugal. Lisboa: Jornal do Fôro. 1950, vol. I, p. 547; SARAIVA, António José - O Crepúsculo da Idade Média em Portugal. Lisboa: Gradiva, 1998, pp. 250-265.

6. Expressão já utilizada por BERTOLI, André - O Cronista e o Cruzado: a revivescência do Ideal Cavaleiresco no Outono da Idade Média Portuguesa (Século XV). Curitiba: Universidade de Curitiba, 2009. Dissertação de Mestrado, p. 42.

7. Para uma biografia de Zurara veja-se DINIS, António J. Dias - Vida e Obras de Gomes Eanes de Zurara. Vol. I, pp. 3-114. Sem querer entrar nas discussões eruditas que têm motivado os especialistas da obra de Zurara em torno da datação das suas obras, as informações apresentadas a seguir têm por base as ideias sintetizadas em FIGUEIREDO, Albano - A Crónica Medieval Portuguesa: génese e evolução de um género (sécs. XIV-XV) - A dimensão estética e a expressividade literária. Coimbra: Universidade de Coimbra, 2005. Tese de Doutoramento, pp. 466-517 e FERNANDES, Adriano - A Crónica do Conde D. Duarte de Meneses de Gomes Eanes de Zurara: estudo histórico-cultural e edição semidiplomática. Vila Real: Universidade de Trás-os-Montes e Alto Douro, 2007, vol. I. Tese de Doutoramento, p. 264.

8. ZURARA, Gomes Eanes de - Crónica da Tomada de Ceuta por el rei D. João I. Ed. Francisco Maria Esteves Pereira. Lisboa: Academia das Ciências de Lisboa, 1915.

9. FIGUEIREDO, Albano - O ideal de cavalaria na crónica da Tomada de Ceuta de Gomes Eanes de Zurara. Coimbra: Universidade de Coimbra, 1996. Tese de Mestrado. Vejam-se ainda FIGUEIREDO, Albano - A Crónica Medieval Portuguesa..., pp. 479-517 e FIGUEIREDO, Albano - “O narrador e o herói na Crónica da Tomada de Ceuta de Gomes Eanes de Zurara”. in Figura: Actas do II Colóquio da Secção Portuguesa da Associação Hispânica de Literatura Medieval. Faro: Faculdade de Ciências Humanas e Sociais da Universidade do Algarve, 2001, pp. 89-109.

10. Debates que envolveram, entre outros, Costa Pimpão, Duarte Leite, Dias Dinis e Torquato de Sousa Soares. Discutiu-se muito se a crónica resultaria ou não da fusão de dois textos, quando teria sido de facto feita essa fusão e em que épocas teriam sido redigidas as diversas partes da narrativa. Este debate tem toda a pertinência para compreender, por exemplo, qual o papel do Infante D. Henrique enquanto personagem e autor/idealizador destas narrativas, questões que permanecem completamente em aberto e suscetíveis de debate. No entanto, estas não constituem o âmago do presente artigo, que procurou responder a outras interrogações, não ignorando, todavia, a pertinência e a importância dos citados problemas.

11. GOMES, Rita Costa - "Zurara and the Empire: Reconsidering Fifteenth-century Portuguese Historiography". Storia della storiografia 47 (2005), p. 67; LEITE, Duarte - Acerca da "Cronica dos Feitos de Guinee". Lisboa: Bertrand, 1941, p. 80; PIMPÃo, Álvaro Júlio da Costa - A "Crónica dos feitos de Guinee": as minhas "teses" e as "teses" de Duarte Leite. Coimbra: Livraria Gonçalves, 1941, p. 14; DINIS, António J. Dias - Vida e Obras de Gomes Eanes de Zurara. Vol. I, pp. 319-351.

12. FIGUEIREDO, Albano - "Viagem, cavalaria e conquista na Crónica de Guiné de Gomes Eanes de Zurara". in Modelo: Actas do V Colóquio da Secção Portuguesa da Associação Hispânica de Literatura Medieval. Porto: Departamento de Estudos Portugueses e de Estudos Românicos - Faculdade de Letras da Universidade do Porto, 2005, pp. 25-33. 
13. ZURARA, Gomes Eanes de - Crónica dos feitos notáveis que se passaram na conquista de Guiné por mandado do infante D. Henrique. Ed. Torquato de Sousa Soares. Lisboa: Academia Portuguesa da História, 1997,Vol. I, pp. 107-109.

14. Assim a considera, entre outros autores, Larry King, que classifica a Crónica dos Feitos da Guiné como "disjuntiva", formando um plano distinto e à parte do ciclo relativamente homogéneo das três obras que têm Marrocos como cenário: KING, Larry - "Introdução", pp. 27-28.

15. Assim as classifica FIGUEIREDO, Albano - A Crónica Medieval Portuguesa..., p. 479.

16. Pelo que reúnem certas características das "biografias cavaleirescas" (expressão de Elisabeth Gaucher) muito em voga na época, como por exemplo os sinais desde tenra idade de que os biografados seriam grandes cavaleiros (sobre D. Duarte de Meneses diz-se "nom se desenfadaua tanto em outra cousas como nos feitos da cauallarya como aquelle que casy do berço husara ho officio das armas": ZURARA, Gomes Eanes de - Crónica do Conde D. Duarte de Meneses, p 49). Veja-se o estudo de GAUCHER, Elisabeth - La Biographie Chevaleresque: typologie d'un genre (XIII-XV siècle). Paris: Honoré-Champion Éditeur, 1994.

17. Aspeto também já sublinhado por PIMPÃo, Álvaro Júlio da Costa - Escritos Diversos. Coimbra: Universidade de Coimbra, 1972, pp. 33-42.

18. ZURARA, Gomes Eanes de - Crónica do Conde D. Duarte de Meneses, p. 107

19. ZURARA, Gomes Eanes de - Crónica do Conde D. Pedro de Meneses, p. 655

20. ZURARA, Gomes Eanes de - Crónica dos feitos notáveis..., p. 59.

21. Veja-se a análise feita acerca destes testemunhos e da sua adaptação à crónica por DUARTE, Luís Miguel - Ceuta, 1415..., pp. 36-40.

22. "E em esta derradeira vollta matarã outro cujo nome esqueçeeo aaquelles de que rreçebemos avisamemto pera escrevermos aqueste llyvro", em ZURARA, Gomes Eanes de - Crónica do Conde D. Pedro de Meneses, p. 342.

23. Os "adaijs e almocadeens e escuitas e outra gente do campo que foram os principaaes meos per que se as cousas ordenarom e fezerom", e que certamente dariam "melhor lembrança dos feitos que os cortesaãos cujo sentido como som no regno ha mais dantender a outras partes", em ZURARA, Gomes Eanes de - Crónica do Conde D. Duarte de Meneses, p. 47.

24. ZURARA, Gomes Eanes de - Crónica do Conde D. Pedro de Meneses, p. 321.

25. ZURARA, Gomes Eanes de - Crónica do Conde D. Pedro de Meneses, pp. 523-524.

26. Veja-se, por exemplo, o detalhado elenco das fontes que terão sido utilizadas para a redação da Crónica da Guiné feito por LEITE, Duarte - Acerca da "Cronica dos Feitos de Guinee", pp. 80-108. Diogo Ramada Curto refere o caráter "miscelânico" das obras de Zurara: CURTO, Diogo Ramada "A Literatura e o Império: entre o espírito cavaleiresco, as trocas da corte e o humanismo cívico". in BETHENCOURT, Francisco e CHAUDHURI, Kirti (dir.) - História da Expansão Portuguesa. Lisboa, Círculo de Leitores, 1998, vol. I, p. 438.

27. ZURARA, Gomes Eanes de - Crónica do Conde D. Pedro de Meneses, p. 585

28. ZURARA, Gomes Eanes de - Crónica do Conde D. Duarte de Meneses, p. 233

29. ZURARA, Gomes Eanes de - Crónica dos feitos notáveis... pp. 133, 213 e 311. Veja-se o que se diz sobre este personagem em BRAGANÇA, José de - "Introdução". in ZURARA, Gomes Eanes de Crónica da Guiné. Porto: Livraria Civilização, 1937, vol. I, pp. XXXVIII-XXXIX; DINIS, António J. Dias - Vida e Obras de Gomes Eanes de Zurara. Vol. I, pp. 443-447.

30. ZURARA, Gomes Eanes de - Crónica do Conde D. Duarte de Meneses, p. 55.

31. GOMES, Rita Costa - "Zurara and the Empire: Reconsidering Fifteenth-century Portuguese Historiography”, pp. 88-89.

32. "Como melhor podemos apremder, assy pelos escriptos daquelles que primeiramemte tomarão cuydado de poerem estes feitos em nembramça como pellas cartas que ho comde escrevia a este rregno e também per aqueles que laa esteverão", em ZURARA, Gomes Eanes de Crónica do Conde D. Pedro de Meneses, p. 545. 
33. GOMES, Rita Costa - "Zurara and the Empire: Reconsidering Fifteenth-century Portuguese Historiography”, pp. 73-75.

34. "ymda que aquy neste vallume achem allguas cousas desvairadas ou mumgoadas da coronica gerall, he por não ser desta callydade e a elle há-de ser primçipallmente emderemçada. E como quer que as cousas que aquy quamto tamger aos feitos da cavalaria vão, na outra cronica não seram escriptos na ordenamça que aquy são", em ZURARA, Gomes Eanes de - Crónica do Conde D. Pedro de Meneses, p. 185.

35. Veja-se o que escreve Rita Costa Gomes acerca de um códice dedicado à ação de Martim Afonso de Melo como fronteiro do Alentejo na década de 1450, e a maneira como esse códice preparado pelo próprio Zurara, teria sido uma espécie de "working dossier", em GOMES, Rita Costa - "Zurara and the Empire: Reconsidering Fifteenth-century Portuguese Historiography", pp. 77-78.

36. Fica explícito de resto numa afirmação colocada por Zurara na boca do rei D. João I: "Como achareys no rregimento dos prymçipes, que muitas vezes em minha camara ledes e ouvis “, em ZURARA, Gomes Eanes de - Crónica do Conde D. Pedro de Meneses, p. 206. Sobre esta tradição em Portugal veja-se BUESCU, Ana Isabel - "Um Discurso sobre o Príncipe: a "pedagogia especular" em Portugal no século XVI". Penélope 17 (1997), pp. 33-50.

37. ZURARA, Gomes Eanes de - Crónica do Conde D. Pedro de Meneses, pp. 179-180.

38. GOMES, Rita Costa - A Corte dos Reis de Portugal..., p. 45, pp. 59-60, p. 108.

39. Antes de mais, é conveniente explicar devidamente o que se quer dizer com o conceito aristocracia, pois este é muitas vezes utilizado em paralelo ou em oposição com nobreza ou fidalguia, gerando-se frequentemente alguns equívocos conceptuais. Neste caso, a utilização do conceito de aristocracia tem como referente o fenómeno de dominação social existente nas sociedades de Antigo Regime, segundo o qual alguns grupos estavam, sob vários pontos de vista, numa posição de predomínio tida como natural e aceitável (ver MORSEL, Joseph - L'aristocratie médiévale. Paris: Armand Colin, 2004, pp. 6-7). Esta questão é importante para compreender a nomenclatura utilizada na medida em que essa dominação não era exercida apenas pelo que convencionalmente se chama nobreza (de resto, e pelo menos até ao século XV, o termo nobre era usado sobretudo como adjetivo, e não como forma de precisar a categoria social do indivíduo), mas também por outros grupos sociais em diferentes circunstâncias. Neste contexto, tenham-se presentes dois exemplos do mundo concelhio: os cavaleiros-vilãos dos séculos XII e XIII, também chamados na bibliografia de "aristocracia vilã" (COELHO, Maria Helena da Cruz - "Aristocracia Vilã”. in COELHO, Maria Helena da Cruz e HOMEM, Armando Luís de Carvalho (coord.) - Portugal em Definição de Fronteiras. Lisboa: Presença, 19, pp. 253-260) ou, no final da Idade Média, os homens bons, espécie de oligarquia endinheirada que controlava as estruturas político-administrativas dessas circunscrições de poder (vejam-se os problemas colocados por DUARTE, Luís Miguel - "Os melhores da terra (um questionário para o caso português)". in BARATA, Filipe Themudo (ed.) Elites e redes clientelares na Idade Média: problemas metodológicos. Lisboa: Colibri e CIDEHUS-EU, 2001, pp. 94-98). Por isso, aristocracia (significando, na sua origem grega, o governo dos melhores) é um conceito operativo mais válido, libertando a análise de divisões porventura demasiado estanques e lineares, e colocando a ênfase nas dinâmicas e interações sociais de modo mais global e compreensivo.

40. A definição de nobreza enquanto grupo social é um fenómeno tardio em Portugal, que passou à margem da discussão típica de Quatrocentos sobre os fundamentos da nobreza e da sua função na sociedade. Neste reino, tais definições só foram elaboradas já na Época Moderna. Vejam-se MONTEIRO, Nuno Gonçalo - O Crepúsculo dos Grandes: a Casa e o Património da Aristocracia em Portugal (1750-1832). Lisboa: Imprensa Nacional Casa da Moeda, 2003, pp. 22-29 e SOUSA, Bernardo Vasconcelos e - "Linhagem e Identidade Social na Nobreza Medieval Portuguesa (Séculos XIIIXIV)”. Hispania LXVII, 227, pp. 896-898. 
41. Sobre o sentido polissémico do termo cavaleiro nas fontes veja-se AGUIAR, Miguel - Ideologia Cavaleiresca em Portugal no Século XV. Porto: Universidade do Porto, 2016. Dissertação de Mestrado, pp. 26-28.

42. ORDENAÇÕES AFONSINAS. Lisboa: Fundação Calouste Gulbenkian, 1998, Livro I, p. 360.

43. ZURARA, Gomes Eanes de - Crónica do Conde D. Pedro de Meneses, p. 197.

44. ZURARA, Gomes Eanes de - Crónica do Conde D. Pedro de Meneses, pp. 482-483.

45. ZURARA, Gomes Eanes de - Crónica do Conde D. Pedro de Meneses, p. 289.

46. ZURARA, Gomes Eanes de - Crónica do Conde D. Duarte de Meneses, pp. 206-207.

47. "soomente a nobreza trazida per antijgas auoengas poem necessydade aos homeens de se quererem alleuantar e estremar antre os outros nos tempos em que se a honra deue aqueryr e buscar por lhes parecer que quanto elles sobreleuam em trabalhos e grandeza de feitos tanto sam mais dignos de mayores e mais excellentes denidades de honra e louuor. E esta he a principal rezom que os esforça a cometer e a ssoportar cousas grandes e fortes de que a outra gente mais baixa aJa mais rezom de se marauilhar que fortelleza nem ousyo pera as cometer nem acabar. $\mathrm{E}$ por isto os excelentes e nobres requerem por fim e gallardom de sseus grandes trabalhos honra e boa fama e os mais baixos requerem rrecompensamento do gaanho", em ZURARA, Gomes Eanes de - Crónica do Conde D. Duarte de Meneses, p. 136.

48. Veja-se AGUIAR, Miguel - Ideologia Cavaleiresca em Portugal no Século XV, pp. 29-66.

49. KAEUPER, Richard W. - Chivalry and Violence in Medieval Europe. Oxford: Oxford University Press, 1999, pp. 135-160.

50. ZURARA, Gomes Eanes de - Crónica do Conde D. Duarte de Meneses, p. 176.

51. ZURARA, Gomes Eanes de - Crónica do Conde D. Duarte de Meneses, pp. 354-355.

52. ZURARA, Gomes Eanes de - Crónica do Conde D. Pedro de Meneses, pp. 292-293.

53. ZURARA, Gomes Eanes de - Crónica do Conde D. Duarte de Meneses, pp. 221-22.

54. ZURARA, Gomes Eanes de - Crónica dos feitos notáveis..., pp. 115-121.

55. ZURARA, Gomes Eanes de - Crónica do Conde D. Pedro de Meneses, pp. 292-293; Crónica dos feitos notáveis..., p. 120.

56. ZURARA, Gomes Eanes de - Crónica do Conde D. Duarte de Meneses, p. 214.

57. MONTEIRO, João Gouveia - "A Cultura Militar da Nobreza na primeira metade de Quatrocentos". Revista de História das Ideias 19 (1997), pp. 195-229.

58. "E os da enssynança da guerra com as cronycas aprovadas he muito perteencente leitura pera os senhores e cavalleiros, e seus filhos, de que se tiram grandes e boos exempros e sabedorias que muyto prestam, com a graça do senhor, aos tempos da necessydade", em DOM DUARTE - Livro da Ensinança de Bem Cavalgar Toda a Sela que fez El-Rey Dom Eduarte. Ed. Joseph M. Piel. Lisboa: Imprensa Nacional Casa da Moeda, 1986, p. 121.

59. Como o rei aconselha ao Infante D. Henrique no regimento que lhe entrega sobre a armada de Tânger: "quando tyuerdes espaço lede per os liuros de guerra e non per outros porque per eles sempre aueres bons conselhos e auysamentos", e "embre uos dacustumar de ler por liuros d auysamentos de pelejas que leua o Jfante dom fernando e o conde $\mathrm{d}$ arrayolos porque em eles açharees muytos auysamentos que em alguas cousas uos podem bem prestar", em DOM DUARTE - Livro dos Conselhos de El-rei D. Duarte (Livro da Cartuxa). Ed. João José Alves Dias e A. H. de Oliveira Marques. Lisboa: Estampa, 1982, pp. 131-132.

60. Recorde-se por exemplo a arenga de D. Pedro de Meneses antes do cerco de Ceuta, ZURARA, Gomes Eanes de - Crónica do Conde D. Pedro de Meneses, pp. 459-462.

61. Veja-se igualmente o estudo de BERTOLI, André - "Modelos de ação bélica na Crônica de D. Duarte de Meneses - Texto, Contexto e Representação”. Mirabilia 15 (2012/2), pp. 171-201.

62. DOM DUARTE - Livro dos Conselhos..., p. 47.

63. DOM DUARTE - Leal Conselheiro. Ed. Maria Helena Lopes de Castro. Lisboa: Imprensa Nacional Casa da Moeda, 1998, pp. 21-22.

64. ZURARA, Gomes Eanes de - Crónica da Tomada de Ceuta, p. 258. 
65. ÁLVARES, Frei João - Trautado da Vida e Feitos do muito Vertuoso S.or Ifante D. Fernando. Ed. Adelino de Almeida Calado. Coimbra: Universidade de Coimbra, 1960, vol. I, pp. 19-20.

66. DOM DUARTE - Livro dos Conselhos..., pp. 135-137.

67. Víctor Gibello Bravo fez um estudo sobre a representação de alguns destes ideais enquanto referenciais da nobreza castelhana. Veja-se GIBELLO BRAVO, Víctor - La Imagen de la Nobleza Castellana en la Baja Edad Media. Cáceres: Universidad de Extremadura, 1995. Vejam-se os estudos de Craig Taylor sobre os escritos ingleses e franceses sobre o tema: TAYLOR, Craig - "English Writings on Chivalry and Warfare during the Hundred Years War". in CROSS, Peter e TYERMAN, Christopher (dir.) - Soldiers, Nobles and Gentlemen: Essays in Honour of Maurice Keen. Woodbridge: Boydell, 2009, pp. 64-84; Chivalry and the Ideals of Knighthood in France during the Hundred Years War. Cambridge: Cambridge University Press, 2013. Nota ainda para o estudo de RODRÍGUEZ VELASCO, Jesús - El Debate sobre la Caballería en el siglo XV: la Tratadística Caballeresca Castellana en su marco Europeo. Salamanca: Junta de Castilla y León, 1996.

68. AGUIAR, Miguel - Ideologia Cavaleiresca em Portugal no Século XV, pp. 124-133.

69. Tópico que remonta ao discurso Pro Archia Poeta, de Cícero.

70. ZURARA, Gomes Eanes de - Crónica do Conde D. Duarte de Meneses, p. 42.

71. Como diz no prólogo do texto dedicado a D. Pedro de Meneses, o objetivo era que os "naturais ouvessem conhecimento e saber das gramdes cavalarias daquele comde e dos outros que com elle comcorrerão", em ZURARA, Gomes Eanes de - Crónica do Conde D. Pedro de Meneses, pp. 175-176.

72. MORSEL, Joseph - L'aristocratie médiévale, pp. 276-279; GOMES, Rita Costa - A Corte dos Reis de Portugal..., p. 160.

73. ZURARA, Gomes Eanes de - Crónica do Conde D. Duarte de Meneses, p. 92 e p. 108.

74. ZURARA, Gomes Eanes de - Crónica do Conde D. Pedro de Meneses, pp. 695-696.

75. ZURARA, Gomes Eanes de - Crónica do Conde D. Duarte de Meneses, p. 173.

76. Este tópico será discutido com maior profundidade no meu artigo "A 'honra' de cavalaria e a aristocracia medieval portuguesa” (Anuario de Estudios Medievales, publicação prevista para 2018).

77. ZURARA, Gomes Eanes de - Crónica do Conde D. Duarte de Meneses, p. 45.

78. Veja-se a nota 22 .

79. Como no exemplo que abriu este artigo, embora Zurara se queixe a certa altura que "os modernos nom quiseram senom breuyedades porem nom curamos descreuer em este liuro senom aquello que sentyrmos que nom podemos scusar", em ZURARA, Gomes Eanes de - Crónica do Conde D. Duarte de Meneses, p. 145.

80. ZURARA, Gomes Eanes de - Crónica do Conde D. Duarte de Meneses, p. 42.

81. GOMES, Rita Costa - "Zurara and the Empire: Reconsidering Fifteenth-century Portuguese Historiography", p. 73

82. ZURARA, Gomes Eanes de - Crónica do Conde D. Pedro de Meneses, p. 175 e p. 718.

83. Veja-se o estudo de CAMPOS, Nuno Silva - D. Pedro de Meneses e a construção da casa de Vila Real (1415-1437). Lisboa: Colibri / CIDEHUS, 2004.

84. ROSA, Maria de Lurdes - O Morgadio em Portugal: Sécs. XIV-XV. Lisboa: Estampa, 1995, p. 49.

85. "o qual conde dom pedro a dicta cidade de cepta huma soo em africa per xpistãos possuida com [muit]a descrisçom xxii anos governou e contr os mouros enfiiees muy esforçadamente defendeo e os conquistou per mar e per terra e fez afastar e per força leixa[r grande parte dos termos della onde por] sua defensom e per a dicta conquista fez muitas peleias en ellas sempre vençedor e nunca vençido de que a dicta cidade ouve sempre em seu tempo gloria de vencimento os mouros temor e os dictos regnos grande louvor", em PONTES, Luís Filipe - Do mundo da corte ao mundo da memória - subsídios para o estudo da mentalidade cavaleiresca da nobreza portuguesa, 1400-1521. Lisboa: Universidade Nova de Lisboa, 2008. Dissertação de Mestrado, p. 146.

86. Como João Gomes da Silva, louvado por ter estado com D. João I "na batalha Real, que houve com el Rei de Castella, na tomada de Ceuta", em PONTES, Luís Filipe - Do mundo da corte ao mundo da memória..., p. 150. 
87. Como é o caso de Martim do Sem e de Fernão Gomes de Góis, in PONTES, Luís Filipe - Do mundo da corte ao mundo da memória..., p. 140 e p. 165.

88. $O$ caso de Vasco Martins de Albergaria, que se diz ter morrido "DAS FERIDAS Q OUUE NA TOMA / DA E NO DESÇERCO DE CEPTA AO ... DIAZ DO MES DE DZ DA ERA DE IHS Xํㅡㄹ DE MIL IIIIC XXX BI ANNOS”, em PONTES, Luís Filipe - Do mundo da corte ao mundo da memória..., p. 145.

89. Para uma revisão da bibliografia sobre este assunto e apresentação de uma perspetiva veja-se AGUIAR, Miguel - Ideologia Cavaleiresca em Portugal no Século XV, pp. 91-117.

90. Sobre Zurara e o Infante D. Henrique veja-se RUSSELL, Peter - Henrique, o Navegador. Lisboa: Horizonte, 2004, pp. 20-21

91. Veja-se um tratamento mais alargado destes pareceres e sua relação com os projetos de cruzada em AGUIAR, Miguel - Ideologia Cavaleiresca em Portugal no Século XV, pp. 99-112.

92. DOM DUARTE - Livro dos Conselhos..., p. 66.

93. DOM DUARTE - Livro dos Conselhos..., pp. 61-63.

94. MONUMENTA HENRICINA. Org. António J. Dias Dinis. Coimbra: Comissão Executiva das Comemorações do V Centenário da Morte do Infante D. Henrique, vol. XIII, pp. 309-3010.

95. MONUMENTA HENRICINA, vol. XIII, pp. 324-328. FONSECA, Luís Adão - "Uma carta do Condestável Dom Pedro sobre a política marroquina de D. Afonso V". Revista da Faculdade de Letras: História I (1970), pp. 83-96.

96. Vejam-se os artigos de ROSA, Maria de Lurdes - "Mortos - "tidos por vivos": o Tribunal Régio e a capacidade sucessória das "Almas em Glória" (Campanhas Norte- Africanas, 1472-c. 1542)". Anais de História de Além-Mar 6 (2005), nomeadamente as pp. 23-43 e "Velhos, novos e mutáveis sagrados...um olhar antropológico sobre as formas "religiosas" de percepção e interpretação da conquista africana (1415-1521)". Lusitânia Sacra 18 (2006), pp. 13-85.

97. ÁLVARES, Frei João - Trautado da Vida e Feitos..., p. 22.

98. Maria de Lurdes Rosa afirma que D. Fernando se torna numa "figura exemplar da doutrina cruzadística (...) oferece-se aos sectores motivados para a expansão africana uma alternativa à morte em batalha: a vida eterna conquistada pelo martírio às mãos dos infiéis". Além disso, a autora também demonstra de que maneira a morte na guerra em Marrocos conferia um estatuto jurídico específico aos que haviam perecido, com implicações específicas, por exemplo, em pleitos de heranças - ROSA, Maria de Lurdes - "Mortos - "tidos por vivos", pp. 39-40. Rita Costa Gomes também salienta o caráter 'documental' que estes textos tinham na época durante os processos de canonização. GOMES, Rita Costa - "Zurara and the Empire: Reconsidering Fifteenthcentury Portuguese Historiography", p. 71

99. ÁLVARES, Frei João - Trautado da Vida e Feitos..., pp. 21-22.

100. DOCUMENTOS DO ARQUIVO HISTÓRICO da Câmara Municipal de Lisboa - Livros de Reis. Lisboa: Câmara Municipal de Lisboa, 1959, vol. 3, p. 277. Também em 1464 D. Fernando da Guerra dá instruções sobre como pregar a cruzada: MONUMENTA HENRICINA, vol. XIV, pp. 290-291.

101. GOMES, Rita Costa - "Zurara and the Empire: Reconsidering Fifteenth-century Portuguese Historiography", p. 67 e pp. 81-82.

102. ZURARA, Gomes Eanes de - Crónica do Conde D. Pedro de Meneses, pp. 175-176.

103. GOMES, Rita Costa - "Zurara and the Empire: Reconsidering Fifteenth-century Portuguese Historiography”, pp. 56-57.

104. Leonor de Portugal, Imperatriz da Alemanha: diário de viagem do Embaixador Nicolau Lanckman de Valckenstein. Ed. Aires de Nascimento. Lisboa: Cosmos, 1992, pp. 37-39.

105. ZURARA, Gomes Eanes de - Crónica do Conde D. Duarte de Meneses, pp. 240-41.

106. AGUIAR, Miguel - Ideologia Cavaleiresca em Portugal no Século XV, pp. 58-59.

107. GAUCHER, Elisabeth - La Biographie Chevaleresque... 


\section{RESUMOS}

Neste artigo pretende-se analisar a produção cronística de Gomes Eanes de Zurara, enquadrando a sua forma e estilo, assim como as mensagens transmitidas, em função dos objetivos que terão presidido à sua feitura. Por um lado, as crónicas destinavam-se a ser 'espelhos de nobres', propondo um conjunto de referenciais cavaleirescos que deviam orientar o comportamento da aristocracia e que, simultaneamente, definiam a matriz de serviço ao rei e da própria competitividade no seio daquele grupo social. Por outro lado, estes textos podem também ser analisados enquanto peças de 'propaganda' favoráveis ao esforço cruzadístico no Norte de África, inscrevendo-se num discurso que visava, nos planos interno e externo, justificar e alimentar o entusiasmo por tal empresa guerreira.

This article aims to analyse Gomes Eanes de Zurara's chronicles, considering not only form and style, but also the message regarding the general purposes of the text. Chronicles were seen as "nobles' mirrors" based on chivalric principles, which functioned as a way of shaping aristocracy's behaviour, while simultaneously defining the competitivity amid that social group. Nonetheless, these texts can also be analysed as pieces of 'propaganda' on behalf of the crusade in North Africa, validating and reinforcing internally and externally the zeal and eagerness of this same movement.

\section{ÍNDICE}

Keywords: Zurara; aristocracy; nobility; chivalry

Palavras-chave: Zurara; aristocracia; nobreza; cavalaria

\section{AUTOR}

\section{MIGUEL AGUIAR}

Universidade do Porto, CEPESE - Centro de Estudos da População, Economia e Sociedade, 4150-564, Porto, Portugal

Université Paris 1 Panthéon-Sorbonne, LaMOP - Laboratoire de médiévistique occidentale de Paris

miguelper.aguiar@gmail.com 